\title{
Образовательные траектории российской элиты: региональная проекция
}

\author{
Н.В. КОЛЕСНИК*
}

\begin{abstract}
*Наталья Владимировна Колесник - кандидат социологических наук, старший научный сотрудник, ученый секретарь, Социологический институт РАН - филиал Федерального научно-исследовательского социологического центра РАН. Адрес: 190005, Санкт-Петербург, 7-я Красноармейская ул., д. 25/14. E-mail: n.kolesnik@socinst.ru
\end{abstract}

Цитирование: Колесник Н.В. (2019) Образовательные траектории российской элиты: региональная проекция // Мир России. Т. 28. № 4. С. 30-48. DOI: $10.17323 / 1811-038 X-2019-28-4-30-48$

В статье анализируются образовательные траектории представителей региональных элит в современной России с ичелью определения специфики их образования и его роли в прочессе воспроизводства элитных общностей. Анализ основан на исследовании 635 структурированных биографий политической и административной элиты Санкт-Петербурга, Ленинградской, Ростовской, Калининградской, Костромской, Хабаровской областей, проведенном в 2011-2016 г2. Полученные результаты свидетельствуют о постепенном отходе от «технократического» образовательного профиля в сторону экономических и юридических специальностей. Зачастую представители региональной элиты являются обладателями нескольких дипломов о высшем образовании и/или ученой степени. Исследование также показывает региональныле различия по количеству силовиков: вылвлено, что чем выше статус во властной вертикали, тем чаще встречаются лица с военным образованием. Важно отметить, что $в$ работе ставится под сомнение идея о существовании пула элитных (элитарных) вузов в современной России ввиду того, что процесс его формирования носит незавершенный характер.

Ключевые слова: региональная элита, образовательные траектории, воспроизводство, образовательный уровень элиты, российский регион, образование

\section{Введение}

В настоящее время образовательные траектории российской элиты являются относительно маргинальным сюжетом в исследовательских социальных проектах. 
Научное игнорирование данной темы объясняется разными причинами, при этом элитологическая проблематика в целом остается важной научной темой. Элиты как высокоресурсные общности практически в любом обществе определяют векторы общественного развития. Более того, изучение элитных общностей позволяет понять степень концентрации власти в том или ином социуме, которая, как отмечает немецкий социолог М. Хартманн, достигается исключительно «за счет эксклюзивного социального рекрутирования при одновременно высокой мобильности между секторами элит» [Hartmann 2000]. Эксклюзивное социальное рекрутирование в первую очередь рассматривается на основе специального образования, полученного в элитарных учебных заведениях, и переходах элиты из одного сектора в другой.

Второй аргумент в пользу изучения образовательных траекторий элиты состоит в том, что особенности первичной и вторичной социализации, влияющие на культурные и образовательные основания представителей данной общности, во многом определяют их ценности. Еще Р. Патнэм не единожды отмечал как важность полученного типа образования, так и его влияние на политические ориентации исследуемой общности [Putnam 1976]. Помимо этого, анализ характера образования представителей элитной общности позволяет выявить, как меняется процесс перераспределения властных ресурсов, и ответить на вопрос о том, каков уровень образования тех, кто занимает властные позиции. Характер полученного образования влияет и на векторы федеральной/региональной политики, поскольку социализация (как первичная, так и вторичная) неизбежно оказывает воздействие на формирование элитного духа - ценности, интересы и предпочтения, степень однородности, сплоченности и интеграции внутри элитной общности.

О значимости полученного образования вообще и типа образования в частности свидетельствуют многочисленные эмпирические исследования. Доказано, что формирование устойчивых ценностей зависит не только от образования как институции или как агента социализации, но и от типа полученного образования. Если студенты американских колледжей в процессе обучения чаще усваивают либеральные взгляды по политическим вопросам, то в профессиональных вузах, например, в медицинских, наблюдается противоположная тенденция. Эмпирические данные Р. Павалко показали, что у студентов-медиков происходит ценностная трансформация, в ходе которой усваиваются убеждения представителей данной профессии, консерватизм в политических вопросах. В первую очередь этот феномен объясняется тем, что студенты-медики находятся в закрытой профессиональной среде, в которую они попадают во время обучения и при последующем трудоустройстве. Кроме того, анализ влияния образования на формирование жизненных позиций и поведения студентов показали, что те, кто обучается в дифференцированном экономическом, этническом, социальном окружении, впоследствии становятся более терпимыми к окружению [Pavalko 1968].

Как отмечают сторонники воспроизводственных теорий социологии образования (С. Боулз, П. Бурдье, Г. Гинтис и другие), высшие и средние учебные заведения уподобляются конвейерам, где лучшее образование предоставляется выходцам из элитных семей. В процессе обучения дети из этой общности приобретают такие качества, как инициативность, решительность, а представителям низших слоев и рабочей среды прививаются следование правилам и покорность [Bourdieu, Passeron 1977]. 
Таким образом, выше обозначенные исследования фиксируют важную идею о том, что тип образования влияет на процесс формирования ценностей индивидов, социальных групп, общностей. Также высшее образование выполняет селективную функцию, что означает неизбежное наличие в обществе социальных дифференциаций в случае выбора учебного заведения тем или иным индивидом.

Ключевой исследовательский вопрос заключается в определении особенностей образования и его роли в процессе воспроизводства российской элиты; предметом исследования являются образовательные траектории региональной элиты в современной России. Представляется, что решение научной проблемы возможно через последовательное предоставление ответов на вопросы, среди которых наиболее значимыми следует назвать (1) выявление характеристик в выстраивании образовательных траекторий представителями элитных общностей российских регионов, (2) определение образовательного профиля региональной элиты при выборе второго высшего и дополнительного образования, (3) описание пула элитных вузов, (4) изучение социальных дифференциаций внутри регионального элитного сообщества через образовательную институцию.

Объектом эмпирического исследования выступает региональная элита, которая определяется как совокупность лиц, занимающих высшие позиции в административных, политических, экономических структурах определенного региона. Отбор единиц исследования или региональных персон производился на основе позиционного подхода, который, впрочем, обладает как преимуществами, так и недостатками ${ }^{1}$. Эмпирическую основу исследования составили первичные данные, полученные в ходе реализации нескольких проектов в 2011-2016 гг., которые были посвящены функционированию региональной власти и элиты в современной России.

Основной сбор эмпирического материала (2011-2016 гг.) осуществлялся методом структурированной биографии ${ }^{2}$. Источниковедческую базу составили биографии, которые вместили в себя информацию об основных этапах профессиональной карьеры, социализации (первичной и вторичной) представителей административной и политической элиты шести российских регионов (СанктПетербурга, Ленинградской, Ростовской, Костромской, Калининградской областей и Хабаровского края). Биографические сведения, полученные из открытых источников, были закодированы и обработаны в соответствии с разработанной анкетойㄱ․

В ходе эмпирического исследования для отбора регионов мы применили комбинированную стратегию, которая в научной литературе называется стратегией противоположных случаев - «наибольшего сходства» и «наибольшего различения» ${ }^{4}$. В отношении случаев Санкт-Петербурга и Ленинградской области следует отметить, что они были включены как некий макрорегион и являют собой пример «наибольшего сходства» как по отношению друг к другу, так и в связи со случаем Калининградской области. Ростовская, Костромская области,

\footnotetext{
Более подробно см.: [Ривера Ш., Ривера Д. 2009; Колесник (2) 2012]).

2 Статистический массив охватывает политический (депутаты региональных парламентов) и административный (региональная исполнительная власть) сегменты рассматриваемых регионов в полном объеме (100\%).

3 О методе структурированной биографии см.: [Колесник (1) 2012].

4 Более подробно о данной исследовательской стратегии см.: Голосов Г.В. (2011) Сравнительная политология. СПб.: Изд-во Европ. Ун-та в С.-Петербурге. С. 49-51.
} 
Хабаровский край представляют собой «различный тип» по отношению к ним. Географическая близость Санкт-Петербурга, Ленинградской и Калининградской областей (северо-западная часть РФ) учитывалась прежде всего в ситуации выбора стратегии «наибольшего сходства». Основным преимуществом данной исследовательской стратегии становится возможность получения обобщений, значимых при проведении сравнительного исследования.

Политическая элита представлена депутатским корпусом, руководителями региональных партий и региональных отделений федеральных партий обозначенных выше российских регионов; в административную элиту вошли главы администраций, председатели комитетов, их заместители, руководители региональных структур, которые находятся в подчинении федеральных органов власти, представители федеральных министерств и ведомств ${ }^{5}$.

\section{Теоретические основания исследования}

\section{Образовательные траектории как исследовательский концепт}

Важным элементом социального воспроизводства выступают образование и образовательные траектории, мы рассмотрим последний концепт более подробно. Французский социолог П. Бурдье предлагает определять их «как серии положений, последовательно занимаемых одним и тем же агентом (или даже группой агентов) в меняющемся, подчиненном нескончаемым трансформациям пространстве» [Бурдье 2002, с. 80]. Он также отмечает, что, когда «биографические события определяются как расстановка и перерасстановка в социальном пространстве, или точнее, в последовательных состояниях которые задействованы в поле», то существует взаимовлияние биографии индивида и социального пространства [Bourdieu 1986, p. 70]. Позиции «прибытия» не являются одинаково вероятными для «пунктов отправления», это означает, что существует очень сильная корреляция между социальными позициями и диспозициями занимающих их агентов [Bourdieu 1986]. По мнению П. Бурдье, и позиция, и индивидуальная траектория не обладают статистической независимостью.

Социолог С. Горард, рассуждая с позиции экономической социологии, определяет образовательные траектории ${ }^{6}$ как некие модели участия в течение всей жизни индивида, которые прогнозируются его социальным происхождением и школьными достижениями. Применительно к индивиду С. Горард достаточно широко трактует понятие «образовательные траектории» и, согласно Г.А. Чередниченко, определяет их как некую совокупность образовательных практик [Чередниченко 2013, с. 61]. В вопросах образовательных траекторий и социального воспроизводства С. Горард, так же как и П. Бурдье, отводит особую роль

\footnotetext{
5 Элита культурной, спортивной, образовательной, научной и других общественных сфер российского общества не являлась объектом исследования.

6 Learning trajectories (перевод Г.А. Чередниченко); в научной литературе существуют и другие переводы этого термина - обучающие траектории, социализирующие траектории.
} 
социальному происхождению, представляющему собой «пункт запуска» траекторий в образовательную систему, который сообщает им направление и место назначения.

В своей теории социального воспроизводства П. Бурдье различает образовательные, профессиональные и социальные траектории, которые могут воспроизводиться на индивидуальном и коллективном уровнях. Таким образом, наиболее перспективным для нашего эмпирического исследования видится использование концепта «траектория» П. Бурдье, который определяет их как некую серию позиций индивида в социальном пространстве, где в свою очередь варьируется множество полей, структурированных в соответствии с закономерностями и правилами, в котором(ых) агент может занимать одну или сразу несколько позиций. Система образования, государство, церковь, по П. Бурдье, являют собой такие поля, в которых неизбежно возникают доминирующие и подчиненные индивиды: «<..> доминирующие в данном поле находятся в позиции, когда они могут заставить его функционировать в свою пользу, но должны всегда помнить о сопротивлении, встречных требованиях, политических или неполитических претензиях тех, кто находится в подчиненном состоянии» [Bourdieu 1992, p. 78].

Исследуемая нами элитная общность определяется как коллективный агент, который находится в объективированной позиции, формируя и контролируя образовательное поле, и образование выступает как некое условие для поддержания и сохранения данной социальной общности, как важная социальная институция для воспроизводства позиций индивида в элитной общности, «как групповое поддержание условий, создающих возможность сохранения власти в “своем кругу”, и, сохранение, стабилизация этого “круга”» [Дука (1) 2012, с. 51].

\section{Образование как фактор сочиального воспроизводства}

Наибольшую теоретическую значимость для дальнейшего рассмотрения образовательных траекторий региональной элиты представляют идеи об образовании как факторе воспроизводства социального статуса. Культурный капитал, по мнению П. Бурдье, активно участвует в процессе воспроизводства социального статуса, и элита как общность, конвертируя ресурсы в образование, использует этот институт для воспроизводства собственных социальных позиций. Следовательно, образование может выступать в роли социального института, в рамках которого и происходит воспроизводство социального статуса индивидов и групп. П. Бурдье еще в 1960-х гг. предложил собственное видение проблем социального неравенства: посредством введения категорий «культурный капитал» и «воспроизводство» он показал, что в обществе образование выполняет селективную функцию и усиливает социальное неравенство [Bourdieu 1977].

В теории learning trajectories C. Горарда социальному происхождению индивида также придается большое значение, и образовательные траектории трактуются автором как совокупность образовательных практик, включающие в себя не только переходы от одного уровня школьного образования к другому, но и иные виды перемещений в рамках института образования, опосредованного социальным происхождением индивида. 
В многочисленных исследованиях европейских и американских элит внимание обращается на относительную закрытость данной общности и существующую связь между социальным происхождением и возможностями воспроизводства своих высоких социальных позиций. Так, по мнению М. Ли, в европейских странах на долю представителей рабочего класса приходится только $7 \%$ мест в административном аппарате, чуть больше в европейских парламентах (22\%). Американский парламент более открыт для социальных низов: в составе палаты представителей от демократической партии доля рабочих составляет 16\%, от республиканской - 25\% [Lee 2012].

Исследования образовательного статуса политической и административной элиты Европы и США указывают на существование дифференциации по типу полученного образования. Согласно данным исследований, более $90 \%$ европейских и американских депутатов и представителей административной элиты имеют высшее образование. Больше всего гуманитариев зафиксировано среди английских чиновников, при этом в США их количество незначительно - 6\%, в Германии еще меньше $-3 \%$. Среди немецких чиновников преобладают юристы - 70\%, значительно их количество в Голландии (40\%), Италии (56\%) и США (20\%). Что касается политической элиты США, то более половины имеют юридическое образование (57\%) (для сравнения: в Великобритании - только 20\%) [Lee 2012].

Следует отметить, что вопросы образования как дифференцирующего фактора в обществе достаточно разработаны как в советской, так и российской социологии [Васильев 1978; Лукина, Нехорошкова 1982; Шкаратан 1978; Тихонова 1999; Бондаренко 2002]. Образование как предмет исследования традиционно оставалось объектом особого внимания ученых и довольно часто рассматривалось в оптике социального воспроизводства. Разработчики этой модели, применяя обширный эмпирический материал, исследовали трудовые коллективы, профессиональные сообщества и городские общности, однако внутренние механизмы и социальные факторы, порождающие различные типы неравенства в обществе, не входили в сферу исследовательского интереса ученых.

Что касается зарубежных исследований, то со второй половины XX в. проблемам социального воспроизводства и образования как дифференцирующего фактора западные ученые стали уделять меньшее внимание. Эту ситуацию О.И. Шкаратан, один из разработчиков теории социального воспроизводства, объясняет относительной устойчивостью этих обществ в конце 1990-х - начале 2000 -х гг. Тем не менее часть западных социологов продолжили изучать проблемы социального воспроизводства, однако работы V. Kaufman, D. Nettle, S. Morgan, D.B. Grusky, G.S. Fields, по мнению О.И. Шкаратана и Г.А. Ястребова, носили, как правило, сравнительный характер или охватывали слишком большой исторический период [Шкаратан, Ястребов 2007, с. 10].

В начале XXI в. в российской социальной науке произошел всплеск интереса к вопросам образования. Анализ эмпирических данных показывает: селективная функция высшего образования постепенно усиливается, что означает начало активного процесса формирования не только группы элитных вузов, но и постепенное сужение возможностей для получения качественного высшего образования представителями низкостатусных групп российского общества. Исследования доказывают, что в престижных вузах России по большей части обучаются студенты из высокодоходных семей, семей с социальными (полезными) связями, те, чьи родители занимают значимое положение в обществе [Шиикин 2006, с. 220]. 


\section{Результаты исследования}

\section{О типе высшего образования региональной элитьл}

Выявление образовательных траекторий региональной элиты представляет собой важную характеристику при воссоздании социального облика элиты шести российских регионов. Анализ эмпирических данных показывает, что среди представителей региональной элиты распространено преимущественно техническое, юридическое, гуманитарное образование, и различия между исследуемыми регионами в отношении типа образования оказались не столь значимыми. Схожие результаты получили и московские исследователи, проанализировавшие биографии представителей федеральной элиты. Было установлено, что преобладающими типами образования среди чиновников президентской администрации, членов правительства, Совета Федерации, депутатов Государственной Думы, представителей судебной и контрольной структур (всего 1340 чел.) являются техническое и технологическое $(14,7 \%)$, гуманитарное $(14 \%)$ и образование, полученное в вузах силовых ведомств $(12,8 \%)$ [Рейтинг вузов 2014]. По нашему мнению, феномен технократизации региональной и федеральной элиты связан не только с общими тенденциями в структуре советского высшего образования, в которой превалировали технические вузы, но и с возрастными особенностями элитной общности. В сегменте административной элиты в период с 2009 по 2014 г. произошли рост доли старших возрастов и некоторое увеличение числа тех, кто имел номенклатурное прошлое; по-прежнему сохраняется относительно периферийный (по месту рождения и получению высшего образования) характер региональной элиты и происходит уменьшение доли администраторов, которые заняли нынешние позиции до 40 лет.

Эмпирические данные за 2005-2007 гг. демонстрируют, что первенство того или иного типа образования в сегменте региональной элиты зависит от возрастной структуры: чем моложе представители элиты, тем меньше распространен среди них технический тип образования, и наоборот. Эту тенденцию подтверждают исследования элиты Санкт-Петербурга, Ленинградской, Калининградской, Ростовской областей, где количество «технарей» в элитной общности снизилось почти на 20\% (с 54\% в 2005-2007 гг. до 35\% в 2012 г.), при этом количество выпускников экономической и юридической специальностей постоянно растет: увеличение произошло в среднем в два раза (экономистов - с 10 до 23\%, юристов с 4 до $9 \%)$.

Вторичный анализ данных обнаружил, что на федеральном уровне в среде элиты невысока доля лиц, имеющих управленческо-политическое и юридическое образование, что является наследием советского времени. Согласно историческим данным, в последней четверти XIX и начале XX вв. российская элита государственного аппарата обучалась преимущественно в Высшем училище правоведения или на юридическом и физико-математическом факультетах императорских университетов. «Более половины министров и товарищей министров народного просвещения в рассматриваемый период имели юридическое образование, а большинство чиновников ЦСУ МВД - математическое» [Рьюжов 2009, с. 242]. Однако 
традиционная подготовка российской элиты на юридических факультетах вузов была прервана революцией 1917 г., и в дальнейшем произошла «технологизация» образовательных траекторий советской элиты. Объясняя технический крен, следует отметить, что в советское время внутри элитной общности протекали процессы, ставшие отражением глобальных сдвигов в системе высшего образования СССР. Если рассматривать биографии представителей региональной элиты на предмет соответствия полученного образования/специальности и занимаемой должности, то можно обнаружить многочисленные примеры рассогласования в образовательном статусе, когда кадровый военный управлял фабрикой или заводом, а бывший строитель или шахтер руководил городской администрацией ${ }^{7}$.

\section{«Силовое» начало в образовательном статусе элитьл}

Вопрос о милитократическом начале в российской элитной общности обсуждался ведущими российскими элитологами (О.В. Крыштановской, Н.В. Петровым, А.В. Дукой и другими). О.В. Крыштановская выявляет, что «поток людей в погонах» пришелся на время президентства В.В. Путина, и уже к началу 2000-х гг. в российских властных структурах каждый четвертый имел военное образование и опыт работы в силовых структурах. Подобный тренд в элитной общности объясняется автором исследования желанием президента-военного упорядочить работу государственных органов, повысить надежность и исполнительность каждого служащего. Более того, «массовое привлечение военных на государственную службу было продиктовано и отсутствием институционального кадрового резерва госслужащих. Советская номенклатура была сильна именно своей методичной работой с таким резервом, который формировали постоянно и для всех уровней власти. Перестройка и последовавшие за ней реформы разрушили этот институт» [Крышттановская 2002, с. 160]. Автор обращает внимание и на относительно низкий уровень образования путинской элиты в начале 2000-х гг., когда произошли снижение роли интеллектуалов, имеющих ученую степень, и увеличение почти в четыре раза числа лиц, получивших военное образование: если в первые два года правления Б.Н. Ельцина доля лиц, имевших военное образование, составляла 6,7\%, то к 2002 г. (при В.В. Путине) их число выросло в четыре раза $(26,6 \%)$ [Крыитановская 2002, с. 160].

Иные результаты масштаба феномена милитократии представляет А.В. Дука [Дука (2) 2012, с. 114]. Существенных свидетельств о наличии или складывающейся милитократии, по данным политолога, проанализировавшего структурированные биографии более 1700 представителей элиты шести российских регионов, не существует. Более того, вхождение во властные позиции в регионах выходцев из силовых структур, по мнению А.В. Дуки, не связано с президентством В.В. Путина: в большей степени силовики представлены в федеральной части региональной элиты, нежели в региональном сегменте, что подтвердили результаты и нашего

\footnotetext{
7 Феномен «расширения практики использования специалистов разного профиля не по назначению» при полном доминировании технических специалистов в структуре подготовки кадров наблюдался в СССР с 1970-х гг., что подтверждается проведенными эмпирическими исследованиями [Руткевич 1994, с. 30-43].
} 
исследования. Таким образом, приведенные данные в целом указывают на значимый тренд (наличие военного образования) в образовательном статусе представителей региональной и федеральной элиты современной России.

Эмпирическое исследование продемонстрировало, что в элитных общностях изученных российских регионов существует очевидная дифференциация по количеству силовиков. Согласно полученным данным, в Ленинградской и Костромской областях и в Санкт-Петербурге силовые структуры являются одним из главных каналов рекрутирования в региональную элиту. Например, в Ленинградской области и в Санкт-Петербурге в целом около 40\% представителей региональной элиты имеют значительный опыт работы в силовых структурах (более 10 лет); в Костромской области и Хабаровском крае каждый четвертый проходил службу в силовых структурах 10 лет и более; в Ростовской и Калининградской областях в прошлом там работали лишь $12 \%$.

На фоне всей исследуемой элиты выделяется региональный сегмент Калининградской области, в которой 50\% представителей элиты имеет юридическое образование (для сопоставления: меньше всего юристов зафиксировано в Хабаровском крае - около 5\%). Примечателен тот факт, что по сравнению с другими регионами среди региональной элиты Калининградской области $11 \%$ находились на службе в силовых структурах более 10 лет, что можно частично объяснить объективными факторами, в числе которых приграничное расположение региона и размещение на его территории еще с советского времени большого количества военных объектов.

Анализ эмпирических данных 2010 г. показал, что первым высшим образованием для 9\% региональной элиты являлось военное (Ростовская, Калининградская области и Хабаровский край). Через 5 лет число силовиков увеличилось: больше всего лиц с военным образованием зафиксировано в калининградской (20\%), ростовской $(17 \%)$ и санкт-петербургской (15\%) элите, а в целом по шести регионам военное образование имеют $13 \%$ представителей региональной элиты.

Определяя количественные характеристики представленности силовиков в региональной элите, важно отметить качественную составляющую. Впервые проблему милитократии как политического режима, формирующегося в современной России, начали обсуждать с вступлением на президентский пост В.В. Путина. Исследователи фиксировали приток силовиков во властные позиции на федеральном и региональном уровнях как в экономике, так и в политике. В международных сравнительных исследованиях также отмечалось, что в политической элите России (на примере парламента) доля силовиков в несколько раз выше, чем в парламентах стран Восточной и Центральной Европы почти в пять раз [Ilonszki, Edinger 2007, с. 149]. В этой связи видится необходимым вовлекать дополнительные параметры, позволяющие определить не только особенности стиля управления силовиков, эффективность принимаемых решений, но и обозначить сегменты силовых структур (КГБ/ФСБ, армия, МВД, ВПК и других), из которых происходит рекрутирование, специфику первичной и вторичной социализации силовиков, степень гетерогенности этой социальной общности и поколенческие характеристики. Принадлежность к поколению, по мнению немецкого элитолога У. ХоффманЛанге, является значимым в рекрутировании элиты, поскольку смена поколений в элите протекает гораздо быстрее, чем в целом среди населения, и выборы могут вызвать в элитах поколенческие сдвиги [Хоффман-Ланге 2017]. 


\section{О вузах, в которых обучается региональная элита}

В российской социальной науке до сих пор отсутствуют серьезные эмпирические исследования, посвященные практикам элитного образования. Многозначным остается и сам термин «элитное образование», вследствие чего возникает вопрос: включает ли он в себя высококачественное образование, когда отбор в учебные заведения осуществляется по меритократическим критериям, либо же он охватывает образовательные учреждения, в которых обучаются те, кто впоследствии займет высшие позиции в социальной иерархии в силу своего происхождения. Даже в такой постановке вопроса очевидным и доказанным на материалах эмпирических исследований представляется факт существования тесной связи между выбором вуза, культурным капиталом и социальным происхождением индивида. Следует подчеркнуть, что в российской социологии часто происходит смешение критериев при определении элитного или элитарного образования, помимо этого, достаточно вольно операционализируется и сам концепт «элитный вуз» ${ }^{8}$.

Если обратиться к истории элитного образования в Европе, то оно насчитывает не одно десятилетие. В развитых странах, за исключением Германии, на протяжении нескольких веков шел процесс формирования элитных учебных заведений, в стенах которых социализировалась будущая национальная элита. Примеры таких образовательных кузниц элиты, как Национальная школа администрирования (ЭНА) во Франции, парижская Политехническая школа, Токийский и Киотский университеты, английские университеты в Оксфорде и Кембридже, вузы американской «Лиги плюща», давно стали хрестоматийными. Главными критериями элитности этих заведений являются качественное и престижное образование, относительная социальная закрытость, сопряженная с высоким происхождением студентов. В данной ситуации элитное образование выполняет социализирующую, интегрирующую функцию, формирующую социальные сети и связи входящих в «ближний круг».

Историю существования элитных образовательных учреждений в России прервала революция 1917 г., но уже позднее высшее образование в СССР обрело все черты социально-дифференцированной институции, в которой появились целые группы головных и привилегированных высших учебных заведений. Как отмечает М.М. Соколов, наследием советской (и отчасти досоветской) конструкции системы высшего образования стало существование подсистем вузов, связанных с профильными министерствами, причем многие состояли из одного института, обслуживавшего непосредственно министерство или ведомство (например, МГИМО при МИД РФ) [Соколов 2017, с. 44-46].

При исследовании образовательных траекторий региональных элитных общностей возникает вопрос о специализации вузов, где получала образование элита того или иного региона. Анализ полученных данных показывает, что элиты Санкт-Петербурга и Ленинградской области при выборе вуза отдавали предпочтение СПбГУ, ЛЭТИ, Инженерно-строительному институту. Такой же набор вузов

8 Исключение составляют результаты коллективного проекта «Анализ доступности высшего образования для социально уязвимых групп», который был выполнен при поддержке Фонда Форда и координирующей роли Независимого института социальной политики. 
в плане отраслевой специализации характерен и для ростовской политической и административной элиты (Ростовский университет, Новочеркасский политехнический институт, Ростовский институт сельскохозяйственных машин). Представители калининградской элиты выбирали Калининградский ГУ, и лишь костромская элита предпочитала получать образование в местном педагогическом вузе. Полученные данные показывают, что по большей части региональная элита обучалась в провинциальных, а не столичных вузах, что повлияло на их стартовые возможности внутри региона9. Хотя есть и исключение: так, представители элиты Хабаровского края чаще получали первое высшее образование в политехнических вузах, военных училищах, военных академиях не только в регионе, но и в Москве. Заметны образовательные дифференциации и по поколениям: молодое поколение (родившиеся в 1970-е гг. и позже) внутри хабаровской элиты чаще выбирало юридические специальности в качестве первого высшего образования, а старшее поколение традиционно предпочитало техническое, военное, гуманитарное, экономическое образование. Следует отметить, что обучение в зарубежных вузах среди региональной элиты носит достаточно ограниченный характер (нами зафиксированы лишь единичные случаи).

Таким образом, образовательные институции, вузы до недавнего времени не играли решающей роли в процессе социальной мобильности региональной элиты. При этом доминирование в структуре российской вузов определенной когорты образовательных учреждений позволяет предположить начавшийся процесс формирования пула вузов, в которых в большинстве случае получали(ют) образование представители региональной элиты. В этом отношении ситуация с образовательным уровнем федеральной элиты несколько отличается от региональной; воспроизводятся практики, когда в профессиональной биографии становится значимым не только диплом элитного вуза (МГУ, МГИМО или СПбГУ), но и тип образования (специализация), годы окончания того или иного вуза (феномен выпускников питерских вузов в администрации президента и в российском правительстве) и принадлежность к определенному кругу. В целом образовательные учреждения не обладают эксклюзивным правом в социальном отборе представителей региональной элиты: известны случаи, когда высшие позиции занимали лица без высшего образования и даже те, у кого диплом о высшем образовании был получен незаконным путем ${ }^{10}$.

\section{Дополнительные ресурсы образовательного капитала}

Одним из элементов образовательного капитала региональной элиты является наличие ученой степени. Полученные данные позволили определить (по сегментам

\footnotetext{
9 Не составляют исключение и представители элитного сообщества Санкт-Петербурга и Ленинградской области, которые получали образование в петербургских вузах (более 89\%), что подтверждает гипотезу о совпадении среди представителей региональной элиты места рождения и получения первого высшего образования.

10 Например, в 2003 г. после обнаружения факта о поддельном дипломе лишился статуса члена Совета Федерации от Ленинградской области Д. Шадаев. Фальшивые дипломы о высшем образовании стали причиной отстранения от должностей А. Донского (мэр Архангельска) и А. Теребилова (мэр Дальнегорска).
} 
региональной элиты), что при защите и кандидатских, и докторских диссертаций наиболее востребованной оказывается экономическая наука вне зависимости от типа элиты - политической или административной. В области экономики докторские диссертации защитили 44,4\% администраторов, 50\% политиков; по педагогической, социологической и политологической наукам - по 11,1\% защищенных докторских диссертаций. Больше всего кандидатов экономических и юридических наук среди администраторов (8,6 и 10,8\% соответственно), среди политиков, защитивших кандидатские диссертации по экономическим наукам, $-6,8 \%$, техническим $-14,7 \%$, медицинским - 9,5\%.

Ожидаемым результатом при подсчете распределений оказалась популярность экономических наук: среди женщин этот показатель достиг $62 \%$, среди мужчин $-45 \%$. Вторые позиции у мужчин занимает техническое образование $(26 \%)$, женщины отдают предпочтение техническим (7\%), юридическим (8\%), политологическим (7\%), педагогическим (8\%), медицинским (8\%) наукам.

Если учитывать гендерные различия среди тех, кто получил ученую степень, то среди кандидатов наук наблюдается относительно равномерное распределение (женщин - 15\%, мужчин - 21\%). Диспропорция в распределении по полу появляется при анализе такой образовательной группы, как доктора наук: среди докторов наук зафиксировано лишь 4\% женщин. Женщины, как правило, получают степень кандидата наук в возрасте до 30 лет, и это прямо пропорционально связано с повышением образовательного статуса. У большинства мужчин, входящих в региональную элиту, защита кандидатской диссертации происходит после 30 лет, и чаще всего мужчины, имеющие степень кандидата, представляют политический сегмент региональной элиты и входят в депутатский корпус (92\%).

Управленческо-политическое образование (46\% мужчин, 55\% женщин), финансово-экономическое образование (24\% мужчин, 21\% женщин), юридическое образование (12\% мужчин, 5\% женщин) одинаково распределены как среди мужчин, так и среди женщин. Особо обращает на себя внимание и то, что 5\% женщин и 4\% мужчин избрали своим вторым высшим образованием военное и военно-медицинское.

Полученные данные показывают, что по уровню образования региональная элита представляет собой высокостатусную общность, в которой почти половина экономической и политической элиты имеет ученые степени. Показательно, что аналогичный порядок наблюдается и в сегменте федеральной элиты: 44,7\% ее представителей имеют ученую степень доктора или кандидата наук (199 докторов наук и 375 кандидатов наук). Более того, как и в случае с региональной элитой, чиновники из федеральной элиты чаще всего защищают диссертации по экономическим (217 чел.) и юридическим (125 чел.) наукам [Рейтинг вузов 2014].

Определяя специфику образовательного профиля региональной элиты в современной России, следует отметить достаточно широкую практику получения представителями этой общности второго и последующего высшего образования, обучение на дополнительных программах повышения квалификации. Если обратиться к многочисленным биографиям региональной элиты, то заметно, что практически каждый третий имеет второе высшее образование, и, как правило, обучение проходит в период профессиональной социализации и без отрыва от работы. 
Основной кузницей для получения второго высшего образования среди административной региональной элиты (реже политической) с 2010 г. стала РАНХиГС (и ее 64 филиала), призванная обеспечить непрерывное образование российских чиновников и депутатов ${ }^{11}$. В стенах Академии народного хозяйства и госслужбы активно функционируют программы повышения квалификации, которые часто оказываются обязательными в случае прохождения аттестации или квалификационных экзаменов среди государственных служащих. Опрос, который проводили сотрудники Северо-Западной академии государственной службы (СЗАГС) в 2010 г., показал, что почти у 43\% государственных и муниципальных служащих выбор программы дополнительного образования (ДПО) был инициирован кадровой службой по месту работы. В последние годы получение ДПО обусловлено институционально и определяется рядом нормативных документов о государственной (гражданской) службе, в которых прописываются значимость дополнительного профессионального образования и периодичность повышения квалификации (раз в три года) [Васеиякий 2011, с. 27].

Значительное число членов региональной элиты имеют дополнительное второе и третье высшее образование. Если обратиться к количественным данным, то каждый третий представитель региональной общности (в основном представители административной элиты) имеет второе и третье высшее образование. Эмпирические исследования 2008 г. по региональным элитам показывают, что «представители элиты получают второе и третье высшее образование уже после вхождения в руководящую должность политико-административной сферы или хозяйственно-экономической сферы, но до занятия нынешней должности» [Дука, Быстрова, Невский, Колесник, 2008, с. 197].

Среди членов региональной элиты определенное распространение имеет такая форма приобретения профессиональных знаний, умений и навыков, как повышение квалификации, включающее прохождение различных краткосрочных курсов и стажировок, а также учеба в аспирантуре. Данные о повышении квалификации (включая аспирантуру) внутри социального сообщества шести регионов распределены следующим образом: в Санкт-Петербурге - 20,9\%, Ленинградской области $-22,2 \%$, Ростовской области - 19,6\%, Костромской - 20,3\%.

\section{Заключение}

Таким образом, полученные данные демонстрируют, что в целом региональная элита в современной России представляет собой высокообразованную социальную общность. Ее образовательный уровень является социальным основанием для конвертирования данного ресурса в иные виды деятельности на рынке труда, которые позволяют не только извлекать высокие доходы, но и воспроизводить свои властные позиции, что становится существенным для функционирования общности региональной элиты. Представители элитной общности дифференцируются не только по месту, но и по типу полученного высшего образования. В отличие от федеральной российской элиты, которая часто получает высшее образование

11 До 2010 г. данную образовательную функцию выполняли региональные академии государственной службы. 
в московских и санкт-петербургских престижных вузах, представители административной и политической элиты регионального уровня чаще всего имеют дипломы о высшем образовании, полученные в местных вузах ${ }^{12}$.

Эмпирические данные фиксируют, что постепенно происходит отход от технократического образовательного профиля элиты в сторону увеличения дипломированных экономистов и юристов. Данный феномен объясняется не только объективными факторами, но и внутренними процессами, которые протекают внутри российской элитной общности, в том числе и омоложением региональной элиты. Отчетливо отслеживается увеличение тех, кто имеет военное образование и опыт службы в силовых структурах. При рассмотрении образовательного уровня региональной элиты важно также изучение дополнительных образовательных характеристик: второй и последующие типы высшего образования, наличие или отсутствие ученой степени, обучение на дополнительных программах повышения квалификации.

В конечном счете в России не существует сформированного пула элитных вузов в силу того, что представители элитной общности получают образование в различных российских и зарубежных вузах, что порождает новые исследовательские вопросы. Например, очевидной становится проблема причинности: попадает ли тот или иной вуз в категорию элитных в виду того, что значительная часть политической и административной элиты обучалась в этом вузе или же статус вуза необходимо определять посредством ранжирования на основе специально разработанного методического инструментария? Относится ли тот или иной вуз к разряду элитных, если он являются опорным в подготовке и переподготовке кадров для государственной системы управления? Эти и другие вопросы требуют дальнейшего изучения, но, скорее всего, для представителей элитной общности обучение в одном вузе будет способствовать формированию сильных социальных связей и высокому уровню доверия, но не станет строгим критерием для вхождения данного вуза в когорту элитных.

Проведенное исследование показывает, что региональная элита СанктПетербурга, Ленинградской, Ростовской, Костромской, Калининградской областей и Хабаровского края по своему образовательному уровню не представляет гомогенного социального образования, и по этой причине шансы в регионах каждого из этих элитных сообществ на воспроизводство себя как некой социальной общности посредством образовательной институции различны. Рассмотренные социальные характеристики региональной элиты свидетельствуют, с одной стороны, о высоком объеме человеческого капитала в данной общности, а с другой, о востребованности со стороны ее представителей различных видов капиталов. Таким образом, складывающийся тип образовательной элитной структуры в российских регионах, а также логика формирования элитной общности последнего десятилетия показывают, что представители региональной элиты в своем большинстве обладают тем необходимым объемом социальных ресурсов, который важен и значим для воспроизводства властвующего субъекта российского общества в постсоветский период. Однако не стоит преувеличивать значимость

12 Не составляют исключение и представители элитного сообщества Санкт-Петербурга и Ленинградской области, которые получали образование в петербургских вузах (более 89\%), что подтверждает гипотезу о совпадении среди представителей региональной элиты места рождения и получения первого высшего образования. 
(как качественной характеристики) полученного высшего образования представителями федеральной/региональной элиты в современной России, поскольку оно в большей степени влияет на однородность социально-структурных характеристик изучаемой элиты и не до конца проясняет вопрос о качестве получаемого высшего образования.

Процесс ранжирования, определение статусных позиций вузов в общей системе российского образования требуют специального исследовательского внимания. Не до конца проясненным остается вопрос и о том, как взаимосвязаны социальное происхождение и образовательный уровень исследованных элитных общностей. Если сведения об уровне и типе образования поддаются верификации, то данные о социальном происхождении региональной элиты оказываются малодоступными для исследователя. Различение элиты в будущих исследованиях на основе «решенческого» и «репутационного» подходов позволит расширить границы понимания формальной и неформальной структуры региональной элиты. Актуальным видится и анализ того, как образовательный уровень региональной элиты влияет на эффективность процесса управления и качество принимаемых решений.

Исследование образовательных траекторий представителей региональной элиты в современной России демонстрирует, что высшие образовательные учреждения до недавнего времени не играли селективной роли в воспроизводстве элиты. Все это не способствует сплоченности и интеграции внутри элитной общности, но в российских реалиях роль «вытягивающего» фактора берут на себя неформальные институты как каналы формирования российской элиты. В частности, семья, ближний круг, родовые кланы, землячества, выстраиваемые социальные сети компенсируют отсутствие элитных вузов и усиливают гомогенный эффект в процессе рекрутирования региональной элиты.

\section{Литература}

Бондаренко В.А. (2002) Эмпирическая модель воспроизводства социального статуса // Мир России. № 4. С. 126-156.

Бурдье П. (2002) Биографическая иллюзия // Интеракция. Интервью. Интерпретация. № 1. C. $75-81$.

Быстрова А.С., Дука А.В., Колесник Н.В., Невский А.В., Тев Д.Б. (2008) Российские региональные элиты: инновационный потенциал в контексте глобализации // Елисеева И.И. (ред.) Глобализация в российском обществе. СПб.: Нестор-История. C. 99-242.

Васецкий А.А. (2011) Педагогическая система дополнительного профессионального образования государственных гражданских служащих // Научные труды Северо-Западной академии государственной службы. Т. 2. № 3. С. 22-31.

Васильева Э.К. (1978) Социально-экономическая структура населения СССР. М.: Статистика.

Дука А.В. (1) (2012) О подходах к анализу властных элит // Управленческое консультирование. № 3. С. 48-55.

Дука А.В. (2) (2012) К вопросу о милитократии: силовики в региональных властных элитах // Дука А.В. (ред.) Властные структуры и группы доминирования. Материалы десятого Всероссийского семинара «Социологические проблемы институтов власти в условиях российской трансформации». СПб.: Интерсоцис. С. 94-120. 
Колесник Н.В. (1) (2012) Два типа биографии элиты: возможности для эмпирического анализа // Дука А.В. (ред.) Властные структуры и группы доминирования: Материалы десятого Всероссийского семинара. СПб.: Интерсоцис. С. 456-472.

Колесник Н.В. (2) (2012) Исследование региональной элиты в России: история вопроса и эмпирические опыты // Управленческое консультирование. № 3. С. 56-73.

Крыштановская О. (2002) Режим Путина: либеральная милитократия? // Pro et Contra. T. 7. № 4. С. $158-180$.

Лукина В.И., Нехорошков С.Б. (1982) Динамика социальной структуры населения СССР. М.: Финансы и статистика.

Рейтинги вузов по образованию представителей элиты государственного управления России-2014 (2014) // Финансовый университет при Правительстве РФ // http://www.old.fa.ru/news/Documents/GovElite.pdf

Ривера Д., Ривера Ш. (2009) К более точным оценкам трансформаций в российской элите // Политические исследования. № 5. С. 149-157.

Руткевич М.Н. (1994) Социальная ориентация выпускников основной школы // Социологические исследования. № 10. С. 30-43.

Рыжов А.Н. (2009) Образовательные приоритеты российского дворянства в последней четверти XIX - начале XX вв. // Вопросы образования. № 4. С. 235-257.

Соколов M.M. (2017) Миф об университетской стратегии. Экономические ниши и организационные карьеры российских вузов // Вопросы образования. № 2. С. 36-73.

Тихонова Н.Е. (1999) Факторы социальной стратификации в условиях перехода к рыночной экономике. М.: РОССПЕН.

Хоффман-Ланге У. (2017) Элиты в Германии: исторические изменения и новые вызовы // Власть и элиты. Т. 4. С. 31-66.

Чередниченко Г.А. (2013) Образовательные и профессиональные траектории молодежи: исследовательские концепты // Социологический журнал. № 3. С. 53-74.

Шишкин С.В. (2006) Элитное и массовое высшее образование: социально-экономические различия // Вопросы образования. № 2. С. 203-222.

Шкаратан О.И. (1978) Промышленное предприятие: социологические очерки. М.: Мысль.

Шкаратан О.И., Ястребов Г.А. (2007) Социально-профессиональная структура населения России. Теоретические предпосылки, методы и некоторые результаты повторных опросов 1994, 2002, 2006 гг. // Мир России. № 3. С. 3-49.

Bourdieu P. (1986) L'illusion biographique // Actes de la Recherche en Sciences Sociales, no $62-63$, p. 69-72.

Bourdieu P., Passeron J-C. (1977) Reproduction in Education, Society and Culture, London.

Bourdieu P. (avec Loic J. D. Wacquant) (1992) Réponses, Paris: Seuil.

Hartmann M. (2000) Class-specific Habitus and the Social Reproduction of the Business Elite in Germany and France // The Sociological Review, vol. 48, no 2, pp. 241-261.

Ilonszki G., Edinger M. (2007) MPs in Post-Communist and Post-Soviet Nations: A Parliamentary Elite in the Making // The Journal of Legislative Studies, vol. 13, no 1, pp. 142-163.

Lee J.M. (2012) The Political Consequences of Elite and Mass Polarization // http://ir.uiowa.edu/etd/3333

Pavalko R.M. (1968) Sociology of Education: a Book of Reading, Itasca: Peacock Publishers.

Putnam R.D. (1977) Elite Transformation in Advance Industrial Societies: an Empirical Assessment of the Theory of Technocracy // Comparative Political Studies, vol. 10, no 3, pp. 383-411. 


\title{
The Educational Trajectories of the Russian Elite: a Regional Projection
}

\author{
N. KOLESNIK*
}

\begin{abstract}
*Natalia Kolesnik - $\mathrm{PhD}$ in Sociology, Senior Researcher, Scientific Secretary, Sociological Institute of the Russian Academy of Sciences, a Branch of the Federal Center of Theoretical and Applied Sociology of the Russian Academy of Sciences. Address: 25/14, 7 Krasnoarmejskaya St., Saint Petersburg, 190005, Russian Federation. E-mail: n.kolesnik@socinst.ru
\end{abstract}

Citation: Kolesnik N. (2019) The Educational Trajectories of the Russian Elite: a Regional Projection. Mir Rossii, vol. 28, no 4, pp. 30-48 (in Russian). DOI: $10.17323 / 1811-038 X-2019-28-4-30-48$

\begin{abstract}
This article analyses the educational trajectories of members of regional elites in contemporary Russia to determine the specifics of education and its role in the process of elite reproduction. It is based on an empirical study of 635 structured biographies of the political and administrative elite of St. Petersburg, Leningradskaya, Rostovskaya, Kaliningradskaya, Kostromskaya, Khabarovskii regions conducted 2011-2016. The findings reveal a gradual movement away from the "technocratic" educational profile of regional elites towards graduates with economic and juristic profiles. Members of the elite often possess several higher education qualifications and/or an doctorate. The study also reveals regional variation in the share of securocrats: in particular, the incidence of military education increases with rank in the power vertical. Importantly, the study casts doubts on the existence of a pool of elite universities involved in elite reproduction. The findings have important implications for regional analysis and the policies of elite recruitment in regions.
\end{abstract}

Key words: regional elite, educational trajectories, reproduction, educational level of elite, Russian region, education

\section{References}

Bondarenko V.A. (2002) Empiricheskaya model' vosproizvodstva sotsial'nogo statusa [The Empirical Model of the Reproduction of Social Status]. Mir Rossii, no 4, pp. 126-156. Bourdieu P. (1986) L'illusion biographique. Actes de la Recherche en Sciences Sociales, no 62-63, pp. 69-72.

Bourdieu P. (2002) Biograficheskaya illyuziya [A Biographical Illusion]. Interaction. Interview. Interpretation, no 1, pp. 75-81.

Bourdieu P., Passeron J-C. (1977) Reproduction in Education, Society and Culture, London. 
Bourdieu P. (avec Loic J. D. Wacquant) (1992) Réponses, Paris: Seuil.

Bystrova A.S., Duka A.V., Kolesnik N.V., Nevskij A.V., Tev D.B. (2008) Rossijskie regional'nye elity: innovatsionnyj potentsial v kontekste globalizatsii [Russian Regional Elites: Innovative Potential in the Context of Globalization]. Globalizatsiya v rossijskom obshchestve [Globalization in Russian Society] (ed. Eliseeva I.I.), Saint Petersburg: NestorIstoriya, pp. 99-242.

Cherednichenko G.A. (2013) Obrazovatel'nye i professional'nye traektorii molodezhi: kontseptsii issledovanij [Educational and Professional Trajectories of Youth: Research Concepts]. Sotsiologicheskij zhurnal, no 3, pp. 53-74.

Duka A.V. (1) (2012) O podkhodakh k analizu vlastnykh elit [About the Ways to Analyze Power Elites]. Upravlencheskoe konsul'tirovanie, no 3, pp. 48-55.

Duka A.V. (2) (2012) K voprosu o militokratii: siloviki v regional'nykh vlastnykh elitakh [On the Question of the Militocracy: the Power Structures in the Regional Power Elites]. Vlastnye struktury i gruppy dominirovaniya: Materialy desyatogo Vserossijskogo seminara «Sotsiologicheskie problemy institutov vlasti v usloviyakh rossijskoj transformatsii [Power Structures and Domination Groups: Materials of the Tenth all-Russian Seminar "Sociological Problems of the Institutions of Power in the Context of Russian Transformation"] (ed. Duka A.V.), Saint Petersburg: Intersotsis, pp. 94-120.

Hartmann M. (2000) Class-specific Habitus and the Social Reproduction of the Business Elite in Germany and France. The Sociological Review, vol. 48, no 2, pp. 241-261.

Hoffmann-Lange U. (2017) Elity v Germanii: istoricheskie izmeneniya i novye vyzovy [Elites in Germany: Historical Change and New Challenges]. Power and Elites, vol. 4, pp. 31-66.

Ilonszki G., Edinger M. (2007) MPs in Post-Communist and Post-Soviet Nations: a Parliamentary Elite in the Making. The Journal of Legislative Studies, vol. 13, no 1, pp. 142-163.

Kolesnik N.V. (1) (2012) Dva tipa biografii: vozmozhnosti dlya empiricheskogo analiza [Two Types of Elite Biography: Opportunities for Empirical Analysis]. Vlastnye struktury $i$ gruppy dominirovaniya: Materialy desyatogo Vserossijskogo seminara «Sotsiologicheskie problemy institutov vlasti $v$ usloviyakh rossijskoj transformatsii [Power Structures and Domination Groups: Materials of the Tenth all-Russian Seminar "Sociological Problems of the Institutions of Power in the Context of Russian Transformation"] (ed. Duka A.V.), Saint Petersburg: Intersotsis, pp. 456-472.

Kolesnik N.V. (2) (2012) Izuchenie regional'noj elity v Rossii: istoriya voprosa i empiricheskie eksperimenty [Studying Regional Elites in Russia: the Historical Context and Empirical Research]. Upravlencheskoe konsultirovanie, no 3, pp. 56-73.

Kryshtanovskaya O.V. (2002) Rezhim Putina: liberal'naya militokratiya? [Putin's Regime: Liberal Militocracy?]. Pro et Contra, vol. 7, no 4, pp. 158-180.

Lee J.M. (2012) The Political Consequences of Elite and Mass Polarization. Dissertation, University of Iowa. Available at: http://ir.uiowa.edu/etd/3333, accessed 31.08.2019.

Lukina V.I., Nekhoroshkov S.B. (1982) Dinamika sotsial'noj struktury naseleniya SSSR [The Dynamics of the Social Structure of the Population of the USSR], Moscow: Finansy i statistika.

Pavalko R.M. (1968) Sociology of Education: a Book of Reading, Itasca: Peacock Publishers.

Putnam R.D. (1977) Elite Transformation in Advance Industrial Societies: an Empirical Assessment of the Theory of Technocracy. Comparative Political Studies, vol. 10, no 3, pp. 383-411.

Rejtingi universitetov po formirovaniyu predstavitelej elity gosudarstvennogo upravleniya $\mathrm{v}$ Rossii [University Rankings on the Formation of Representatives of the Elite of Public Administration in Russia] (2014). Financial University of the Government of the Russian Federation. Available at: http://www.old.fa.ru/news/Documents/GovElite.pdf, accessed 31.08.2019.

Rivera D., Rivera Sh. (2009) K bolee tochnym otsenkam transformatzii v rossijskoj elite [To More Accurate Estimates in the Transformation of the Russian Elite]. Polis. Political Studies, no 5, pp. 149-157.

Rutkevich M.N. (1994) Sotsial'naya orientatsiya vypusknikov osnovnoj shkoly [Social Orientation of Graduates of Primary School]. Sotsiologicheskie issledovaniya, no 10 , pp. 30-43. 
Ryzhov A.N. (2009) Obrazovatel'nye prioritety russkogo dvoryanstva v poslednej chetverti XIX - nachale XX vv. [Educational Priorities of the Russian Nobility in the Last Quarter of the Twentieth - Early Twentieth Centuries]. Problemy obrazovaniya, no 4, pp. 235-257.

Shishkin S.V. (2006) Elitnoe i massovoe vysshee obrazovanie: sotsial'no-ekonomicheskie razlichiya [Elite and Mass Higher Education: Socio-economic Differences]. Voprosy obrazovaniya, no 2, pp. 203-222.

Shkaratan O.I. (1978) Promyshlennoe predpriyatie: sotsiologicheskie ocherki [The Industrial Enterprise: a Sociological Essay], Moscow: Mysl'.

Shkaratan O.I., Yastrebov G.A. (2007) Sotsial'no-professional'naya struktura naseleniya Rossii. Teoreticheskie predposylki, metody i nekotorye rezul'taty povtornykh oprosov 1994, 2002, 2006 [Socioprofessional Structure of Russian Population. Theoretical Background, Methods and Some of the Results of Repeated Surveys in 1994, 2002, 2006]. Mir Rossii, no 3, pp. 3-49.

Sokolov M.M. (2017) Mif o strategii universiteta. Ekonomicheskie nishi i organizatsionnaya kar'yera rossijskikh vuzov [The Myth of the University Strategy. Economic Niches and Organizational Careers in Russian Universities]. Voprosy obrazovaniya, no 2, pp. 36-73.

Tikhonova N.Y. (1999) Faktory sotsial'noj stratifikatsii v usloviyakh perekhoda $k$ rynochnoj ekonomike [Factors of Social Stratification in the Transition to a Market Economy], Moscow: ROSSPEN.

Vasetskij A.A. (2011) Pedagogicheskaya sistema dopolnitel'nogo professional'nogo obrazovaniya gosudarstvennykh sluzhashchikh [The Pedagogical System of Adult Professional Education for Civil Servants]. Nauchnye trudy Severo-Zapadnoj Akademii gosudarstvennoj sluzhby, vol. 2, no 3, pp. 22-31.

Vasil'yeva Y.K. (1978) Sotsial'no-ekonomicheskaya struktura naseleniya SSSR [Socio-economic Structure of the Population of the USSR], Moscow: Statistika. 